\title{
Serological Studies Using Polyclonal Antisera Prepared Against the Viral Coat Protein of Four Begomoviruses Expressed in Escherichia coli
}

\author{
A. M. Abouzid, J. Freitas-Astua, and D. E. Purcifull, Department of Plant Pathology, University of Florida, Gaines- \\ ville 32611-0680; J. E. Polston, Gulf Coast Research and Education Center, Bradenton, FL 34203; K. A. Beckham, \\ W. E. Crawford, M. A. Petersen, and B. Peyser, Department of Plant Pathology, University of Florida; C. Patte, Gulf \\ Coast Research and Education Center; and E. Hiebert, Department of Plant Pathology, University of Florida
}

\begin{abstract}
Abouzid, A. M., Freitas-Astua, J., Purcifull, D. E., Polston, J. E., Beckham, K. A., Crawford, W. E., Petersen, M. A., Peyser, B., Patte, C., and Hiebert, E. 2002. Serological studies using polyclonal antisera prepared against the viral coat protein of four begomoviruses expressed in Escherichia coli. Plant Dis. 86:1109-1114.

Polyclonal rabbit antisera were produced to the coat protein of Bean golden mosaic virus Brazil isolate (BGMV), Cabbage leaf curl virus (CabLCV), Tomato yellow leaf curl virus (TYLCV), and Tomato mottle virus (ToMoV), all expressed in Escherichia coli by the pETh expression vector. The expressed coat protein of each virus was purified by sodium dodecyl sulfate-polyacrylamide gel electrophoresis for use as an immunogen. The antisera to BGMV, CabLCV, TYLCV, and ToMoV reacted in indirect (plate-trapping) enzyme-linked immunosorbent assay (ELISA) with extracts from begomovirus-infected tissue. The antisera to BGMV, CabLCV, TYLCV, and ToMoV also reacted specifically with the test begomovirus antigens in leaf imprint blots and Western blots. The CabLCV and TYLCV antisera were used to detect Bean golden yellow mosaic virus antigens by immunogold labeling of thin sections of infected bean tissues. In tissue blot immunoassays, the TYLCV antiserum reacted well with TYLCV antigens but not with ToMoV antigens, while CabLCV antiserum reacted well with ToMoV antigens and weakly with TYLCV antigens. The results indicate that polyclonal antisera prepared to expressed begomovirus coat proteins were useful for the detection of begomoviruses in an array of assays.
\end{abstract}

The family Geminiviridae is composed of plant viruses with characteristic geminate particles and containing genomes consisting of one or two molecules of circular single-stranded DNA. The Geminiviridae family, which mostly occurs in tropical and subtropical regions, comprises four genera: Mastrevirus, Topocuvirus, Curtovirus, and Begomovirus (8,19,33). The genus Begomovirus is the largest with 107 accepted and proposed species (33). Viruses belonging to the genus Begomovirus for the most part have bipartite genomes (exceptions include some species and strains of Tomato yellow leaf curl virus [TYLCV], which have monopartite genomes) and are transmitted by whiteflies to dicotyledonous plants (23). The complete nucleotide sequences of many of the geminiviral genomes have been determined,

Corresponding author: E. Hiebert

E-mail: ehi@mail.ifas.ufl.edu

The research was supported by USA-AID Grant DHR-5600-G-00-0056-00 and USDA T-Star Project 95-34135 -1858. J. Freitas-Astua was supported by a fellowship from the National Council of Brazil (CNPq). Florida Agricultural Experiment Stations Journal Series Paper R-08679.

Accepted for publication 20 May 2002.

Publication no. D-2002-0726-01R

(C) 2002 The American Phytopathological Society enabling studies of the similarities and differences between genomes and genes of various geminiviruses. The coat proteins of the begomoviruses have higher amino acid sequence similarity than those of the other Geminiviridae genera $(11,23)$. Begomoviruses are serologically related when tested with antibodies prepared to coat proteins of purified begomoviruses $(5,10,12,13,18,21$, 27,31). However, routine detection and identification using serology has not been as common for geminiviruses as for other plant viruses.

In this study, we tested whether polyclonal antibodies prepared to geminiviral coat proteins expressed in Escherichia coli would be useful in developing inexpensive and simple immunological reagents for detecting begomoviruses. The pETh expression vector has been used successfully to express structural and nonstructural viral genes of potyviruses and begomoviruses $(5,7,34,35)$. Previously we expressed the coat protein of Bean golden mosaic virus, (Brazil isolate) (BGMV) using this system and generated monoclonal antibodies to this protein (5). In this article, we demonstrate that polyclonal antibodies prepared to the coat proteins of BGMV, Cabbage leaf curl virus (CabLCV; 29), TYLCV, and Tomato mottle virus (ToMoV), obtained from coat protein genes expressed in $E$. coli, are useful in detecting and distinguishing viruses of the Begomovirus genus.

\section{MATERIALS AND METHODS}

Virus cultures. The BGMV, Bean golden yellow mosaic virus Dominican Republic isolate (BGYMV-DR), and BGYMV-Guatemala isolate (BGYMV-GA) were obtained as previously described (5). Cultures of these isolates and the BGYMVHomestead isolate (BGYMV-H; 4) were maintained in common bean (Phaseolus vulgaris L. 'Top Crop'). CabLCV (1) was obtained by biolistic inoculation of cabbage (Brassica oleracea L. var. capitata) with infectious clones of CabLCV DNA A and B (A. M. Abouzid, J. O. Strandberg, and E. Hiebert, unpublished). CabLCV also was maintained in cabbage by whitefly transmission and in Nicotiana benthamiana Domin. plants by mechanical inoculation. The ToMoV culture (2) was maintained in $N$. benthamiana and in tomato (Lycopersicon esculentum L. 'Florida Lanai') by whitefly transmission. Sida mosaic virus was obtained from the naturally infected weed, Sida santaremensis Monteiro var. krapovickasiana Monteiro, which is found commonly in Florida (3). TYLCV was obtained from a field-collected isolate in Florida and was maintained in tomato by whitefly transmission (24).

Construction of the coat protein genes in the expression vector plasmid. Based on the sequence of BGMV (9), its coat protein gene was amplified by polymerase chain reaction (PCR) from viral DNA using primers (5' GGG GAA TTC ATG CCT AAG CGT GAT 3' [viral sense] and 5' GGG GGA TCC AAG CTT CTG GGA CGA 3' [complementary sense]). The amplified BGMV coat protein gene, which included 168 nucleotides (nt) downstream from the stop codon, was purified by agarose gel electrophoresis, digested with EcoRI and BamHI, and subcloned into the EcoRI/BglII sites of the pETh-3c expression vector (20). The CabLCV coat protein gene was amplified from the DNA A component by PCR (Genebank U65529) (1) using the viral sense primer (5' GGG AAG CTT ATG TGA TTT CAA TTT $3^{\prime}$ ) and Blue Script vector primer T3 (Stratagene, La Jolla, CA). The amplified CabLCV coat protein gene, which included 50 nt downstream from the stop codon, was digested with HindIII and BglII and subcloned into the pETh-3c expression vector. The ToMoV coat protein gene was constructed by excising a $C l a \mathrm{I}-\mathrm{Xba \textrm {I }}$ fragment from To- 
MoV A component clone (2), which contained the coat protein gene minus $30 \mathrm{nt}$ from the $5^{\prime}$ end (protein lacks 10 amino acid (aa) residues at the N-terminus; 28). The excised fragment was blunt ended (T4 DNA polymerase reaction) and subcloned into the Smal site of the expression vector pETh-3b (20). The TYLCV coat protein gene was amplified from a TYLCV clone (obtained from Hezi Antignus, Israel) using PCR primers 5' GCC GCC GAA TTC AAG CTT ACT ATG TCG AAG 3' (viral sense) and 5' GCC GCC CTT AAG TTC GAA ACT CAT GAT ATA 3' (complementary sense). The PCR product was cloned into the pGEM-T vector and subcloned into the pETh-3c expression vector using HindIII and SacI restriction sites. Each viral coat protein produced from the $\mathrm{pETh}$ expression vector generated a fusion protein containing approximately 14 to 20 aa residues of the bacteriophage T7 gene 10 at the $\mathrm{N}$-terminus of the viral coat protein.

Expression and purification of the coat proteins. The recombinant plasmids were transformed into $E$. coli BL21DE3pLysS (30) and grown in LuriaBertani (LB) medium containing ampicillin $(50 \mathrm{mg} / \mathrm{ml})$ and chloramphenicol $(25$ $\mathrm{mg} / \mathrm{ml}$ ). For induction of the viral coat proteins, cells were grown in M9 medium until they reached 0.4 to 0.6 optical density (OD). Isopropyl-D-thiogalactoside was then added to a final concentration of 0.4 $\mathrm{mM}$ and cells were incubated for another 3 h. Cells were harvested by centrifugation and resuspended in buffer $(20 \mathrm{mM}$ Tris-Cl, $\mathrm{pH}$ 8.0, 1 mM EDTA). Cells were frozen at $-20^{\circ} \mathrm{C}$ for at least $4 \mathrm{~h}$, thawed, and vortexed. One volume of the disrupted cell extract was mixed with one volume of Laemmli dissociation buffer, boiled, and loaded on preparative $10 \%$ sodium dodecyl sulfate-polyacrylamide gel electrophoresis (SDS-PAGE; 15) gels. The expressed coat protein bands were visualized with icecold, $0.2 \mathrm{M} \mathrm{KCl}$, excised, and eluted with a Bio-Rad Model 422 Electro-Eluter (BioRad Laboratories, Hercules, CA) according to the manufacturer's instructions. The eluted proteins of CabLCV, BGMV, TYLCV, and ToMoV were dialyzed against water at room temperature to remove free SDS and then freeze dried before use as immunogens.
The immunogenicity of the expressed CabLCV coat protein prepared without SDS solubilization also was tested. The $E$. coli cells containing the expressed CabLCV coat protein were resuspended in ice-cold Tris- $\mathrm{NaCl}$ buffer $(20 \mathrm{mM}$ Tris$\mathrm{HCl}, \mathrm{pH} 8.0 ; 200 \mathrm{mM} \mathrm{NaCl})$. After centrifugation, the pellet was resuspended in cold lysis buffer (20 mM Tris-HCl, pH 7.4; $500 \mathrm{mM} \mathrm{NaCl} ; 10 \%$ glycerol; $1 \mathrm{mM}$ EDTA; 0.1\% NP 40), sonicated, frozen, and thawed. The lysate was centrifuged at $10,000 \times g$ for $10 \mathrm{~min}$ at $4^{\circ} \mathrm{C}$. One volume of $4^{\circ} \mathrm{C}$ water was added to the supernatant, and then one volume of saturated ammonium sulfate (dropwise) was added to a final concentration of $33 \%$. The mixture was incubated on ice for $15 \mathrm{~min}$ and centrifuged at $10,000 \times g$ for $10 \mathrm{~min}$ at $4^{\circ} \mathrm{C}$, after which the pellet was resuspended in lysis buffer. After centrifugation at 10,000 $\times g$ for $5 \mathrm{~min}$ at $4^{\circ} \mathrm{C}$, the supernatant, which contained the expressed protein, was dialyzed against water at $4{ }^{\circ} \mathrm{C}$ and freeze dried before use as an immunogen.

Immunizations. Antibody to the expressed coat protein of CabLCV, collected from SDS-PAGE, was prepared by intramuscular immunization of a rabbit with antigen emulsified with Freund's adjuvant (complete adjuvant for the first injection and incomplete adjuvant with all subsequent injections) (antiserum \#1200). For each immunization date, the volume of emulsified antigen was divided equally among four sites. For the first injection, a total of $1.67 \mathrm{mg}$ in $1 \mathrm{ml}$ in the complete adjuvant was injected. After 1 week, a similar amount in incomplete adjuvant was administered, followed 1 week later by $0.96 \mathrm{mg}$ in $0.6 \mathrm{ml}$. Two months later, a booster injection of $2.2 \mathrm{mg}$ in $1 \mathrm{ml}$ was given. Antisera collected weekly for several weeks after this booster shot were used in the present study. The rabbits immunized with gel-purified proteins of ToMoV (antiserum \#1175), BGMV (antiserum \#1195), and TYLCV (antiserum \#1214) followed a similar protocol, except that each injection consisted of $2 \mathrm{mg}$ and the booster injections were 12 to 15 weeks after the third weekly injections. Immunization of the expressed CabLCV coat, which was not gel purified (antiserum \#1196), followed a similar protocol, except that the three initial weekly injections consisted of $5 \mathrm{mg}$ each and a booster injection consisting of $2.6 \mathrm{mg}$ was administered 4.5

Table 2. Enzyme-linked immunosorbent assay (ELISA) values from analyses of different plant species infected by either Cabbage leaf curl virus (CabLCV), Bean golden yellow mosaic virus (BGYMV), Tomato mottle virus (ToMoV), or Tomato yellow leaf curl virus (TYLCV) in antigentrapped ELISA, using antisera to CabLCV, Bean golden mosaic virus (BGMV), and ToMoV in antigen-trapped ELISA

\begin{tabular}{|c|c|c|c|c|}
\hline \multirow[b]{2}{*}{ Antigens } & \multicolumn{4}{|c|}{ Antisera $^{a}$} \\
\hline & CabLCV \#1200 & BGMV \#1195 & ToMoV \#1175 & TYLCV \#1214 \\
\hline \multicolumn{5}{|l|}{ CabLCV-infected } \\
\hline Cabbage & $0.949^{(2 / 1)}$ & $0.184^{(2 / 2)}$ & $0.194^{(1 / 1)}$ & $0.594^{(3 / 3)}$ \\
\hline Tobacco & $0.168^{(2 / 1)}$ & $0.129^{(1 / 1)}$ & N/A & N/A \\
\hline \multicolumn{5}{|l|}{ BGYMV-infected } \\
\hline 'Topcrop' beans & $0.473^{(2 / 1)}$ & $0.090^{(5 / 2)}$ & $0.062^{(4 / 2)}$ & $0.566^{(3 / 2)}$ \\
\hline \multicolumn{5}{|l|}{ ToMoV-infected } \\
\hline 'Fla lanai' tomatoes & $0.708^{(1 / 1)}$ & $0.171^{(2 / 2)}$ & $0.132^{(2 / 2)}$ & $0.318^{(2 / 2)}$ \\
\hline \multicolumn{5}{|l|}{ TYLCV-infected } \\
\hline 'Fla lanai' tomatoes & $0.032^{(1 / 1)}$ & $0.037^{(2 / 2)}$ & $0.033^{(3 / 2)}$ & $0.136^{(3 / 2)}$ \\
\hline \multicolumn{5}{|l|}{ Healthy controls } \\
\hline H cabbage & $0.017^{(1 / 1)}$ & $0.028^{(2 / 2)}$ & $0.048^{(1 / 1)}$ & $0.244^{(3 / 3)}$ \\
\hline $\mathrm{H}$ tobacco & $0.024^{(1 / 1)}$ & $0.004^{(1 / 1)}$ & N/A & N/A \\
\hline H 'Topcrop' beans & $0.008^{(1 / 1)}$ & $0.018^{(2 / 2)}$ & $0.020^{(2 / 2)}$ & $0.090^{(2 / 2)}$ \\
\hline H 'Fla lanai' & $0.033^{(1 / 1)}$ & $0.021^{(2 / 2)}$ & $0.020^{(2 / 2)}$ & $0.034^{(2 / 2)}$ \\
\hline
\end{tabular}

a Antisera dilutions: CabLCV, BGMV, and ToMoV = 1:2,500; TYLCV = 1:3,500. Numbers in parentheses indicate number of samples tested/number of experiments performed, respectively. Average readings of all samples tested, two replications per sample. Positive samples ( $>2$ times average readings after 40 to $60 \mathrm{~min}$ of incubation). $\mathrm{NA}=$ not available.

Table 1. Enzyme-linked immunosorbent assay (ELISA) values from analyses of Cabbage leaf curl virus (CabLCV)-infected cabbage using antisera to CabLCV, Bean golden mosaic virus (BGMV), and Tomato mottle virus (ToMoV) in antigen-trapped ELISA ${ }^{\mathrm{a}}$

\begin{tabular}{|c|c|c|c|c|c|c|c|c|}
\hline \multirow[b]{3}{*}{ Antiserum } & \multicolumn{8}{|c|}{ Antiserum-dilutions } \\
\hline & \multicolumn{2}{|c|}{$1: 2,000$} & \multicolumn{2}{|c|}{$1: 4,000$} & \multicolumn{2}{|c|}{$1: 8,000$} & \multicolumn{2}{|c|}{$1: 10,000$} \\
\hline & $\mathbf{I}$ & $\mathbf{H}$ & $\mathbf{I}$ & $\mathbf{H}$ & $\mathbf{I}$ & $\mathbf{H}$ & $\mathbf{I}$ & $\mathbf{H}$ \\
\hline $\begin{array}{l}\text { CabLCV } \\
\# 1200\end{array}$ & 3.00 & 0.09 & 2.16 & 0.01 & 1.79 & 0.01 & 1.95 & 0.00 \\
\hline $\begin{array}{l}\text { CabLCV } \\
\# 1196\end{array}$ & 3.00 & 0.15 & 1.99 & 0.05 & 1.46 & 0.05 & 1.29 & 0.03 \\
\hline BGMV \#1195 & 1.59 & 0.10 & 0.72 & 0.01 & 0.53 & 0.02 & 0.43 & 0.01 \\
\hline ToMoV \#1175 & 1.17 & 0.62 & 0.62 & 0.01 & 0.37 & 0.00 & 0.32 & 0.00 \\
\hline
\end{tabular}

${ }^{a} \mathrm{I}=$ infected cabbage, $\mathrm{H}=$ healthy cabbage. Absorbance values $\left(A_{405}\right)$ represent replicated readings, taken $1 \mathrm{~h}$ after incubation with the substrate. 
months after the third weekly injection. Antisera were collected as previously described (25) and stored frozen or freeze dried until use.

Indirect plate-trapped enzyme-linked immunosorbent assay. A modification of the plate-trapped (antigen added first) enzyme-linked immunosorbent assay (ELISA; 6,17) was used for detection of the begomoviruses. Young, upper leaves of infected (symptomatic) and noninfected plants were ground with a mortar and pestle at a ratio of 1 part tissue to 10 volumes of buffer (35 mM NaHCO $3,15 \mathrm{mM}$ $\mathrm{Na}_{2} \mathrm{CO}_{3}$, and $0.2 \%$ bovine serum albumin [BSA], pH 9.6). Tissue extracts were centrifuged at $1,500 \times g$, the supernatants were collected, and then $100 \mu \mathrm{l}$ was loaded in each well of 96-well, flat-bottom polystyrene ELISA plates (Fisher Scientific, Pittsburgh, PA). The plates were incubated at $37^{\circ} \mathrm{C}$ for $1 \mathrm{~h}$, and the wells were washed three times with phosphate-buffered saline containing $0.05 \%$ Tween 20 (PBST). Each well was loaded with $100 \mu \mathrm{l}$ of antiserum diluted in conjugate buffer (PBST containing $0.2 \% \mathrm{BSA}$ ). The plates were incubated at $37^{\circ} \mathrm{C}$ for $1 \mathrm{~h}$, and the wells were washed three times as before. Alkaline phosphatase-conjugated goat anti-rabbit immunoglobulin G (IgG; Sigma-Aldrich, St. Louis) at a dilution of $1: 10,000$ to 30,000 (vol:vol) in conjugate buffer was added $(100 \mu \mathrm{l}$ per well), and the plates were incubated at $37^{\circ} \mathrm{C}$ for $1 \mathrm{~h}$. The plates were washed as previously described with an added wash with substrate buffer and the reactions were recorded 15 to 60 min during incubation at room temperature (RT) after the addition of substrate (p-nitrophenyl phosphate at $1 \mathrm{mg} / \mathrm{ml}$ in $10 \%$ diethanolamine, $\mathrm{pH}$ 9.8) at $A_{405} \mathrm{~nm}$ in a microplate autoreader EL 309 (Bio-Tek, Winooski, VT). Reactions were considered positive when the absorbance values were equal to or greater than two times the healthy tissue extract values. Absorbance values represent the average of replicated readings.

Western blotting. Young, upper leaves of infected (symptomatic) and noninfected plants were ground in $1.5 \%$ SDS in sterile water and one volume of the extract was mixed with one volume of Laemmli dissociation buffer. The mixtures were boiled for $2 \mathrm{~min}$ and the samples were separated in $10 \%$ by SDS-PAGE and then transferred to nitrocellulose membranes using a BioRad Mini Trans-Blot cell (Bio-Rad Laboratories). The membranes were washed in Tris-buffered saline and $0.25 \%$ Tween 20 (TBST), blocked in Blotto (TBST plus 5\% powdered skim milk) for $15 \mathrm{~min}$ at RT. The membranes were incubated with the polyclonal antisera at 1:1,000 in Blotto for $1 \mathrm{~h}$ at RT. Membranes then were washed three times with TBST and incubated for $1 \mathrm{~h}$ at RT in Blotto containing alkaline phosphatase-conjugated goat anti-rabbit $\mathrm{IgG}$ (Sigma-Aldrich) at a dilution of 1:1,000. After three washings with TBST and a final wash with substrate buffer $(0.1 \mathrm{M}$ Tris- $\mathrm{HCl}$, $\mathrm{pH} 9.5 ; 0.1 \mathrm{M} \mathrm{NaCl} ; 5 \mathrm{mM} \mathrm{MgCl} 2)$, the conjugate was visualized by incubation in a substrate buffer containing nitro blue tetrazolium $(750 \mu \mathrm{g} / \mathrm{ml})$ and 5-bromo-4-chloro3-indolyl phosphate $(500 \mu \mathrm{g} / \mathrm{ml})$.

Leaf imprint blots. A modification of the direct tissue blot method (14) was tested for detecting the begomoviruses. The upper sides of infected (symptomatic) and noninfected leaves were gently brushed with a paintbrush, and then the fully extended leaves were placed on a nitrocellulose membrane (Bio-Rad Transblot Transfer Medium; Bio-Rad Laboratories). The membrane was sandwiched between two sheets of chromatography paper ( $0.35 \mathrm{~mm}$ thickness; Fisher Scientific), and two plexiglass plates $(10$ by $10 \mathrm{~cm})$. A metal disc was placed on top of the assembly. The sandwich was subjected to pressure with a tissue press to ensure even contact of the leaf tissue with the membrane. The membranes were washed once with TBST buffer for $5 \mathrm{~min}$, and the serological reactions were determined as described in the Western blot protocol.

Tissue blots. Young, upper leaves of infected (symptomatic) and noninfected tomato plants were rolled longitudinally into a tight scroll (16). The scroll was folded once before the leaf tissue was cut with a razor blade. The cut leaf surface was immediately held on the surface of a nitrocellulose membrane ( 0.45 micron; Bio-Rad Transblot Transfer Medium) for 6 to $8 \mathrm{~s}$ and the membrane was allowed to air dry. The membrane strips containing tissue blots from various plant samples to be tested for serological reactions were incu- bated in blocking buffer (Western-Light Chemiluminescent Detection System; TROPIX, Inc., Bedford, MA) at RT for 60 min or at $4{ }^{\circ} \mathrm{C}$ overnight. After blocking, the membranes were incubated with the primary antiserum at a dilution of 1:5,000 to $1: 20,000$ for $60 \mathrm{~min}$. The immunological reactions on the membranes were detected according to the manufacturer's (TROPIX, Inc.) instructions.

Transmission electron microscopy and immunolabeling. BGYMV-infected bean plants ( $P$. vulgaris 'Top Crop') were sampled by transmission electron microscopy. Tissue was fixed in a mixture of $2 \%$ glutaraldehyde and $2 \%$ paraformaldehyde, dehydrated in a graded ethanol series, and infiltrated with and embedded in LR White resin (22). Samples were allowed to polymerize at $55^{\circ} \mathrm{C}$.

Thin sections were collected on formvar-coated grids, and blocked with $0.5 \%$ ovalbumin or $0.5 \%$ normal goat serum. Grids were incubated with one of three sera at a 1:100-500 (vol:vol): anti-CabLCV polyclonal antiserum \#1200, anti-TYLCV polyclonal antiserum \#1214, and preimmune rabbit serum. After thorough washing, grids that were incubated with the polyclonal antiserum or normal rabbit serum were incubated with goat anti-rabbit IgG-gold (20 nm) conjugate (EY Laboratories, Inc. San Mateo, CA). Following washing, sections were stained with $2 \%$ aqueous uranyl acetate and lead citrate (26).

\section{RESULTS}

ELISA. Antisera-titration reactions using either CabLCV-infected cabbage extracts or BGYMV-infected bean tissue (data not shown) indicated that the two anti-CabLCV sera (\#1196 and \#1200) had the highest titer or reactivity in indirect ELISA for the detection of bipartite begomoviruses (Tables 1 and 2). The antiCabLCV (\#1200), anti-BGMV (\#1195), and anti-ToMoV (\#1175) sera failed to give positive reactions in limited tests with TYLCV-infected tomato. The anti-TYLCV serum (\#1214) generally gave positive results in ELISA with extracts from TYLCVinfected tomato, strong reactions with BGMV-H-infected tissue extracts, and positive reactions with CabLCV- and ToMoVinfected tissue extracts (Tables 2 and 3 ).

Table 3. Antiserum \#1214 titration using Tomato yellow leaf curl virus-infected tomato tissue in antigen-trapped indirect enzyme-linked immunosorbent assay ${ }^{\mathrm{a}}$

\begin{tabular}{|c|c|c|c|c|c|c|c|c|c|}
\hline \multicolumn{10}{|c|}{ Antiserum-dilutions ${ }^{\mathbf{b}}$} \\
\hline \multicolumn{2}{|c|}{ 1:1,000 } & \multicolumn{2}{|c|}{$1: 2,000$} & \multicolumn{2}{|c|}{$1: 2,500$} & \multicolumn{2}{|c|}{$1: 5,000$} & \multicolumn{2}{|c|}{$1: 10,000$} \\
\hline I & $\mathbf{H}$ & I & $\mathbf{H}$ & I & $\mathbf{H}$ & I & $\mathbf{H}$ & $\mathbf{I}$ & $\mathbf{H}$ \\
\hline 0.395 & 0.183 & 0.168 & 0.012 & $\ldots$ & $\ldots$ & $\ldots$ & $\ldots$ & $\ldots$ & $\ldots$ \\
\hline 1.77 & 0.227 & 0.801 & 0.058 & $\ldots$ & $\ldots$ & $\ldots$ & $\ldots$ & $\ldots$ & $\ldots$ \\
\hline 0.583 & 0.319 & $\ldots$ & $\ldots$ & 0.461 & 0.181 & 0.315 & 0.110 & 0.188 & 0.046 \\
\hline
\end{tabular}

${ }^{a}$ Results from three experiments using extracts from tomato (cv. Homestead) leaves collected from plants of similar age, and from a similar position in different plants. Antiserum was preabsorbed with extracts from healthy tomato leaves (1:50 or 1:75) prepared in phosphate-buffered saline (PBS). PBS buffer, $\mathrm{pH} 7.4$, at $4^{\circ} \mathrm{C}$ overnight. All other steps were similar to the ones already described, except that the dilution of the conjugate was 1:30,000 in PBS instead of PBS containing $0.05 \%$ Tween 20.

${ }^{\mathrm{b}} \mathrm{I}=$ infected tissue, $\mathrm{H}=$ healthy tissue, $\ldots=$ not tested. 
ELISA of tomato extracts with all the sera often had very high background readings (data not shown). However, the background values for the 'Florida Lanai' tomato cultivar were significantly lower than and 3 and data not shown). The assay results (Table 3) in different experiments show some of the background variability even though the TYLCV antiserum was cross-absorbed with healthy tomato tissue extract. As the anti-TYLCV serum dilution increased, healthy and infected tissue extracts could easily be differentiated, based on our $2 \times$ positive threshold (Table 3 ).

Western blots. Begomovirus coat protein was readily detected in Western blots of total protein extracts from infected for other tomato cultivars tested (Tables 2

plants with antisera to coat protein of BGMV, CabLCV, and ToMoV (Figs. 1 and 2). The two CabLCV antisera gave the strongest reactions. The anti-TYLCV serum gave weaker heterologous reactions than those of the other begomovirus coat protein antisera (Fig. 2). The TYLCV coat protein appeared slightly larger than the other begomovirus coat proteins in the blots (Fig. 2B). This is consistent with the molecular weights calculated from the sequence data for the begomoviruses $(5,23)$.

Leaf imprint blots. BGYMV antigens were detected on nitrocellulose membranes with antisera to BGMV, ToMoV, and both CabLCV antisera after infected bean leaves were abraded and pressure blotted onto the

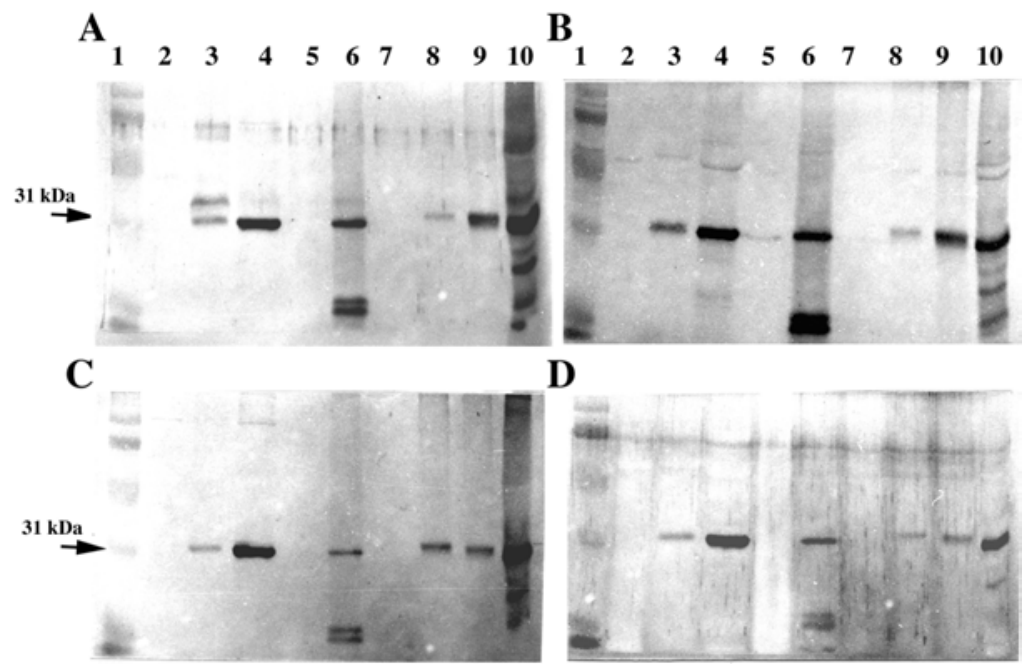

Fig. 1. Western blot analysis of various begomoviruses with A, polyclonal anti-Cabbage leaf curl virus (CabLCV) \#1200; B, polyclonal anti-CabLCV \#1196; C, polyclonal anti-Bean golden mosaic virus (BGMV) \#1195; and D, polyclonal anti-Tomato mottle virus (ToMoV) \#1175. Prestained protein size markers (Life Technologies, Rockville MD) (lane 1); crude plant extracts from noninfected tomato (lane 2); Sida mosaic virus in Sida (lane 3); ToMoV in Nicotiana benthamiana (lane 4); noninfected cabbage (lane 5); CabLCV in cabbage (lane 6); noninfected bean (lane 7); BGMV in bean (lane 8), Bean golden yellow mosaic virus (BGYMV-DR) Dominican Republic isolate) in bean (lane 9); and BGYMV-H (Homestead isolate) in bean (lane 10). The arrow on the left marks the position of the begomovirus coat protein (approximately $31 \mathrm{kDa}$ ). Note the faint reaction in panel $\mathrm{B}$ lane 5, presumed to be due to leakage of begomovirus-infected tissue extract from lane 4 into this lane. The significance of the immunoreactive products smaller than virion coat protein for the lanes (6 and 10) for CabLCV and BGYMV-H extracts is not known.

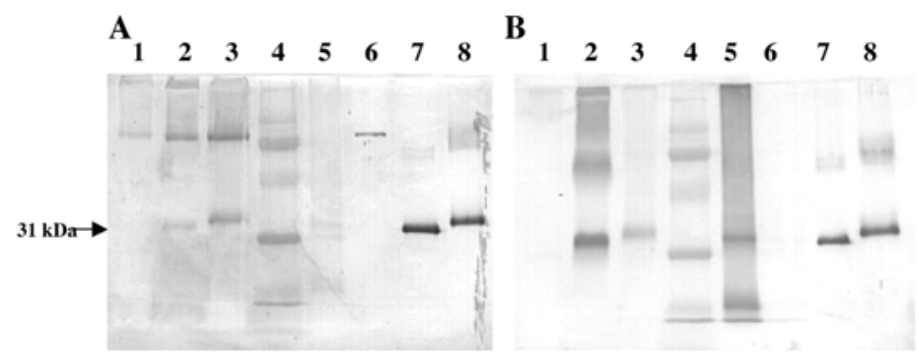

Fig. 2. Western blot analysis of various begomoviruses with A, polyclonal anti-Tomato yellow leaf curl virus (TYLCV) \#1214 and B, polyclonal anti-Cabbage leaf curl virus (CabLCV) \#1200. Crude plant extracts from noninfected tomato (lane 1); Tomato mottle virus (ToMoV)-infected tomato (lane 2); TYLCV-infected tomato (lane 3); prestained protein size markers (lane 4); CabLCV-infected cabbage (lane 5), noninfected cabbage (lane 6); ToMoV coat protein expressed in Escherichia coli (lane 7); TYLCV coat protein expressed in E. coli (lane 8). The arrow on the left marks the approximate position of the begomovirus coat protein in the blot. Note that the coat protein for TYLCV appears to be slightly larger than the coat protein of the other two begomoviruses. membrane (Fig. 3). The distribution of the immunoreaction signal indicated that most of the BGYMV coat protein antigen was concentrated in the vascular system of the infected leaves. Similar results were obtained when $N$. benthamiana leaves infected with CabLCV were tested (data not shown).

Tissue blots. Viral antigens were readily detected on membranes when cut surfaces from leaf tissues infected by ToMoV or TYLCV were blotted (Fig. 4). Polyclonal anti-CabLCV \#1200 antiserum at a 1:5,000 dilution reacted very well with blots from ToMoV-infected leaves but only weakly with blots from TYLCV-infected leaves (Fig. 4). Polyclonal anti-TYLCV \#1214 antiserum at a dilution of 1:20,000 reacted with blots from TYLCV-infected leaves but only very weakly with blots from noninfected tomato leaves (Fig. 4). No reaction with antiserum \#1214 was detected with blots from ToMoV-infected leaves (Fig. 4). Both sera gave detectable reactions to these viruses (Fig. 4) at dilutions up to 1:40,000 (not shown).

Transmission electron microscopy and immunolabeling. Numerous nuclear inclusions, which could be quite large, were present in phloem parenchyma nuclei of bean cells infected with BGYMV. Inclusions consisted of aggregates of begomovirus particles (Fig. 5) and fibrillar rings (not shown). Specific labeling of virions was obtained using anti-CabLCV \#1200 antiserum. Fibrillar rings were not labeled. A nuclear inclusion immunolabeled using anti-CabLCV \#1200 is shown in Figure 5A. At higher magnification, individual virions were discernible (Fig. 5B). Immunolabeling tests with anti-TYLCV (\#1214) antiserum resulted in similar labeling of BGYMV particles (data not shown). These results are consistent with positive results obtained when using heterologous antisera in Western blots and ELISA. The other anti-begomovirus antisera were not tested here.

\section{DISCUSSION}

Polyclonal antisera prepared to four different begomovirus coat proteins expressed in $E$. coli served as useful serological probes for begomoviruses in ELISA, Western blots, leaf imprint blots, tissue blots, and immunogold labeling in electron microscopy. The reactivity of the antisera varied in terms of titer and specificity. The CabLCV antiserum \#1200 had a high titer and broad spectrum of reactivity whereas the BGMV antiserum \#1195 had the least reactivity of the five antisera. The antiserum (\#1196) prepared to CabLCV coat protein not denatured by SDS was not significantly different in serological reactivity, in limited testing, to that prepared to SDS-denatured coat protein (\#1200). The ELISA tests with tomato extracts gave variable results and often were compromised by high absorbance values for the 
control (noninfected) samples (Table 3 and data not shown), thus limiting this assay for begomovirus detection in tomato. The Western blot tests (Figs. 1 and 2) indicated that the CabLCV antiserum \#1200 was very reactive, detecting at least seven species or isolates of begomoviruses. The ability to distinguish the begomoviruses in Western blots was limited by the crossreactivity with the different sera. However, TYLCV could be distinguished from the other begomoviruses in the Western blots on the basis of its slower coat protein migration and its limited serological reactivity. The sensitivity of begomovirus detection in the leaf imprint blots was evident when similar bean leaves infected with BGYMV-H were blotted and probed by hybridization with BGYMV-H DNA A labeled with $\mathrm{P}^{32}$ (data not shown). The simple leaf cross section blot assays of tomato infected with ToMoV or TYLCV indicated that this assay could distinguish between the two viruses using antisera \#1200 reactive with ToMoV and \#1214 reactive with TYLCV (Fig. 4).

The serological reactions of the anti-begomovirus coat protein polyclonal sera indicated their versatility in reacting with begomovirus antigens in the denatured state (Western blots) and undenatured state (ELISA, leaf imprint blots, leaf tissue blots, and ultrathin sections). In ELISA, the CabLCV antiserum was the best probe for detecting the bipartite begomoviruses (high readings with infected tissue extracts and with low background with noninfected tissue extracts). Interestingly, although no antiserum produced against the bipartite begomoviruses could detect TYLCV in ELISA, TYLCV antiserum \#1214 reacted positively to all of the begomovirus coat protein antigens in that test (Table 2). TYLCV antiserum also detected bipartite begomoviruses in Western blots and BGYMV-H antigens in thin sections of infected tissues (data not shown). In tissue blots, TYLCV antiserum showed useful specificity in detecting only TYLCV antigen and not ToMoV antigen (Fig. 4).

A comparison of the predicted amino acid sequences of begomovirus coat proteins indicated most of the sequence variability is limited to N-terminal 60 to 70 aa residues $(5,23)$. The remainder of the coat protein structure is highly conserved among the begomoviruses; therefore, serological cross-reactivity is expected. The Western blot analysis indicated that the TYLCV coat protein was slightly larger than the coat protein for the other begomoviruses (Fig. 2B). This is consistent with the molecular weights calculated from the sequence data for the begomoviruses $(5,23)$.

Previously, we described three monoclonal antibodies prepared to BGYMV isolates and BGMV which were useful in detecting and distinguishing BGYMV isolates from the Caribbean (isolates from
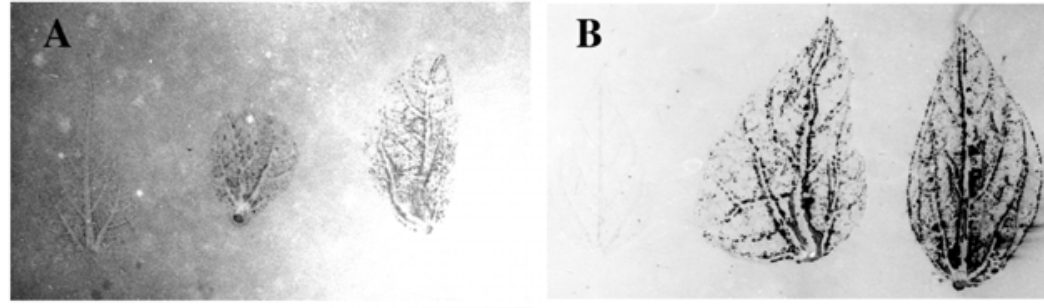

C
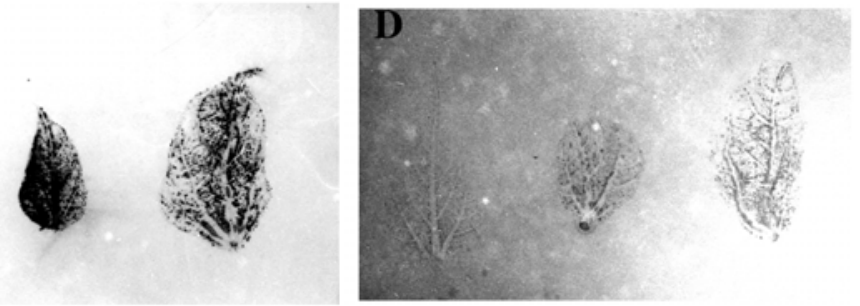

Fig. 3. Leaf imprint blots of noninfected 'Top Crop' bean (Phaseolus vulgaris) leaves and Bean golden yellow mosaic virus (Homestead isolate)-infected bean leaves with A, polyclonal antiCabbage leaf curl virus (CabLCV) \#1200; B, polyclonal anti-Bean golden mosaic virus \#1195; C, polyclonal anti-CabLCV \#1196; and D, polyclonal anti-Tomato mottle virus \#1175. In A to D from left to right: noninfected leaf; infected leaf, developing leaf; and infected mature leaf.

\section{TYLCV ToMoV H. tomato}

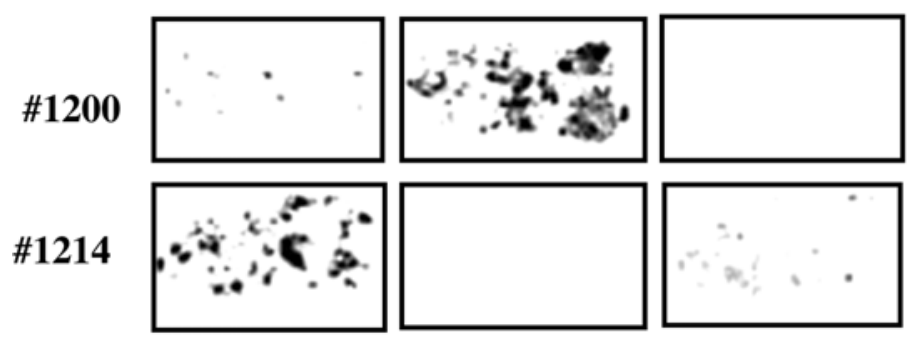

Fig. 4. Tissue blots of cross sections of tomato leaves infected with Tomato yellow leaf curl virus (TYLCV), Tomato mottle virus (ToMoV), and noninfected tomato (H. tomato). The blots were reacted with polyclonal antiserum to Cabbage leaf curl virus coat protein (\#1200) diluted to 1:5,000 and to TYLCV coat protein (\#1214) diluted to 1:20,000. The immunoreactions were detected with alkaline phosphatase-labeled goat anti-rabbit immunoglobulin $\mathrm{G}$ antibodies and a chemiluminescent substrate.

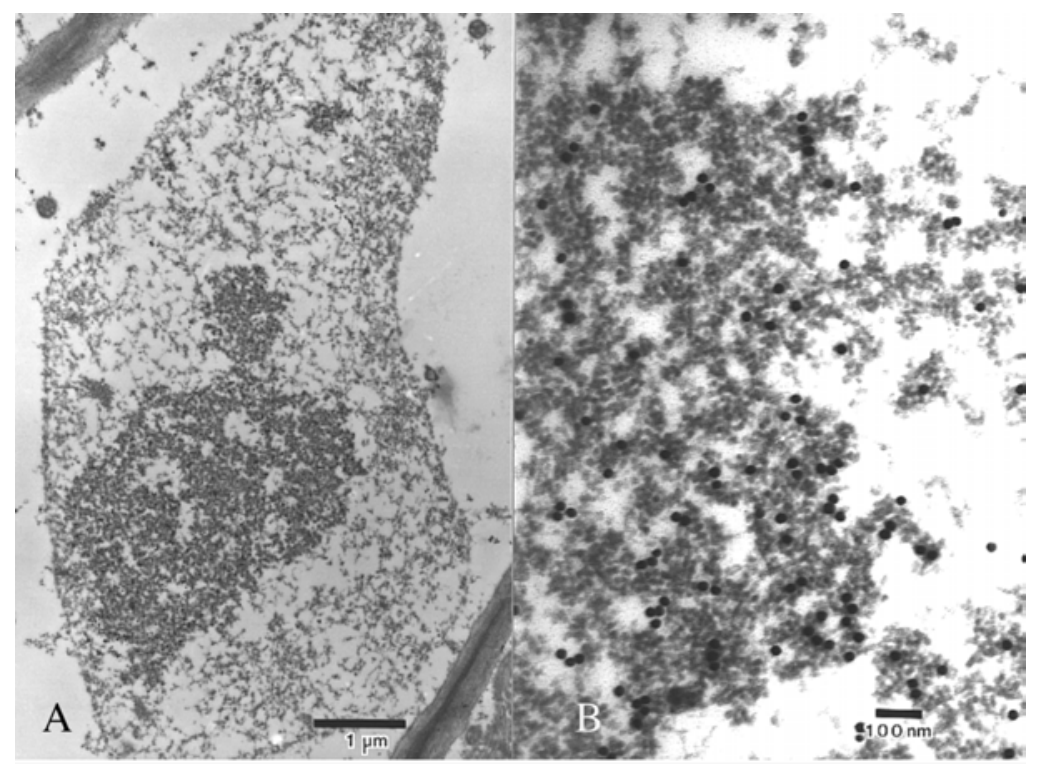

Fig. 5. Thin section of Bean golden yellow mosaic virus (Homestead isolate)-infected bean leaf treated with Cabbage leaf curl virus \#1200 antiserum diluted 1:500, followed by detection with goat anti-rabbit immunoglobulin $\mathrm{G}$ conjugated to $20 \mathrm{~nm}$ of gold diluted 1:100. A, Immunogold label over a nuclear inclusion in a phloem parenchyma cell nucleus. B, A higher magnification view of the nuclear inclusion showing immunogold labeled virions. Bar $=1 \mu \mathrm{m}$ and $100 \mathrm{~nm}$ in $\mathrm{A}$ and $\mathrm{B}$, respectively. 
Guatemala, Puerto Rico, and Dominican Republic) and BGMV from Brazil (5). The broad spectrum monoclonal (3F7) has been used to detect whitefly-transmitted begomoviruses affecting food and industrial crops throughout Latin America (21). The most specific (5C5) of the three monoclonal antibodies prepared to BGYMV (5) has been used to demonstrate that the begomoviruses infecting beans in Brazil, Bolivia, and Argentina are all related and constitute a unique species different from the BGYMV isolates in Central America, Southern Mexico, and the Caribbean (21). This exemplifies how serological diagnostic probes are still useful in the developing countries because PCR technology is not accessible to the great majority of the diagnosticians (F. Morales, personal communication).

In this article, we have described some characteristics of polyclonal antibodies prepared to geminiviral proteins expressed in E. coli. These serological probes are relatively inexpensive to produce (32), are useful for the detection of begomoviruses, and negate the need to obtain, propagate, and purify virions for use as an immunogen (i.e., TYLCV in this article). They may lack the serological specificity of monoclonal antibodies but they still can be used to distinguish begomoviruses in certain cases. The detection of begomoviruses by ELISA using the broad spectrum monoclonal (3F7) required antibody-trapped antigen for high sensitivity (5). Here we demonstrated a rapid (approximately $4 \mathrm{~h}$ ), inexpensive, and sensitive indirect ELISA for the detection of begomoviruses with probes developed against begomovirus coat proteins expressed in E. coli.

\section{LITERATURE CITED}

1. Abouzid, A. M., Hiebert, E., and Strandberg, J. O. 1992. Cloning, identification, and partial sequencing of the genomic components of a geminivirus infecting the Brassicaceae. (Abstr.) Phytopathology 82:1070.

2. Abouzid, A. M, Polston, J. E., and Hiebert, E. 1992. The nucleotide sequence of tomato mottle virus, a new geminivirus isolated from tomatoes from Florida. J. Gen. Virol. 73:3225-3229.

3. Abouzid, A. M., Polston, J. E., and Hiebert, E. 1995. Adaptability of Sida mosaic geminivirus during infection in new hosts. (Abstr.) Phytopathology 85:1139.

4. Blair, M. W., Basset, M. J., Abouzid, A. M., Hiebert, E., Polston, J. E., McMillan, R. T., Jr., Graves, W., and Lamberts, M. 1995. Occurrence of bean golden mosaic virus in Florida. Plant Dis. 79:529-533.

5. Cancino, M., Abouzid, A. M., Morales, F. J., Purcifull, D. E., Polston, J. E., and Hiebert, E.
1995. Generation and characterization of three monoclonal antibodies which are useful in detecting and distinguishing bean golden mosaic viruses. Phytopathology 85:484-490.

6. Converse, R. H., and Martin, R. R. 1990. ELISA methods for plant viruses. Section IV.A.1, pages 179-196 in: Serological Methods for Detection and Identification of Viral and Bacterial Pathogens. R. Hampton, E. Ball, and S. De Boer, eds. American Phytopathological Society Press, St. Paul, MN.

7. Duan, Y. P., Hiebert, E., Purcifull, D. E., and Powell, C. A. 1995. Serological detection of tomato mottle virus nonstructural proteins. (Abstr.) Phytopathology 85:1210.

8. Fauquet, C. M., Maxwell, D. P., Gronenborn, B., and Stanley, J. 2000. Revised proposal for naming geminiviruses. Arch. Virol. 145:17431761 .

9. Gilbertson, R. L., Faria, J. C., Ahlquist, P., and Maxwell, D. P. 1993. Genetic diversity in geminiviruses causing bean golden mosaic disease: the nucleotide sequence of the infectious cloned DNA components of a Brazilian isolate of bean golden mosaic geminivirus. Phytopathology 83:709-715.

10. Givord, L., Fargette, D., Kounounguissa, B., Thouvenel, J. C., Walter, B., and Van Regenmortel, M. H. V. 1994. Detection of geminivirus from tropical countries by a double monoclonal antibody ELISA using antibodies to African cassava mosaic virus. Agronomie 14:327-333.

11. Harrison, B. D., and Robinson, D. J. 1988. Molecular variation in vector-borne plant viruses: epidemiological significance. Phil. Trans. R. Soc. Lond. Ser. B 321:447-462.

12. Harrison, B. D., and Robinson, D. J. 1999. Natural genomic and antigenic variation in whitefly-transmitted geminiviruses (Begomoviruses). Annu. Rev. Phytopathol. 37:369398.

13. Harrison, B. D., Swanson, M. M., McGrath, P., and Fargette, D. 1991. Patterns of antigenic variation in whitefly-transmitted geminiviruses. Annu. Rep. Scott. Crop Res. Inst. 1990:88-90.

14. Hsu, H. T., Lawson, R. H., Lin, N. S., and Hsu, Y. H. 1995. Direct tissue blot immunoassay for analysis of plant pathogens. Pages 367-376 in: Molecular Methods in Plant Pathology. P. R. Singh and U. S. Singh, eds. CRC Press LLC, Boca Raton, FL.

15. Laemmli, U. K. 1970. Cleavage of structural proteins during the assembly of the head of bacteriophage T-4. Nature 227:680-685.

16. Lin, N. S., Hsu, Y. H., and Hsu, H. T. 1990. Immunological detection of plant viruses and a mycoplasmalike organism by direct tissue blotting on nitrocellulose membranes. Phytopathology 80:824-828.

17. Lommel, S. A., McCain, A. H., and Morris, T. J. 1982. Evaluation of indirect enzyme-linked immunosorbent assay for the detection of plant viruses. Phytopathology 72:1018-1022.

18. Macintosh, S., Robinson, D. J., and Harrison, B. D. 1992. Detection of three whitefly-transmitted geminiviruses occurring in Europe by tests with heterologous monoclonal antibodies. Ann. Appl. Biol. 121:297-303.

19. Mayo, M. A. and Pringle, C. R. 1998. Virus taxonomy-1997. J. Gen. Virol. 79:649-657.
20. McCarty, D. R., Hattori, T., Carson, C. B Vasil, V., Lazar, M., and Vasil, I. K. 1991. The viviparous-1 developmental gene of maize encodes a novel transcriptional activator. Cell 66:895-905.

21. Morales, F. J., and Anderson, P. K. 2001. The emergence and dissemination of whiteflytransmitted geminiviruses in Latin America. Brief Review. Arch. Virol. 146:415-441.

22. Newman, G. R., Jasani, B., and Williams, F. D. 1982. The preservation of ultrastructure and antigenicity. J. Microsc. 127:RP5-RP6.

23. Padidam, M., Beachy, R. N., and Fauquet, C. 1995. Classification and identification of geminiviruses using sequence comparisons. J. Gen. Virol. 76:249-263.

24. Polston, J. E., McGovern, R. J., and Brown, L. G. 1999. Introduction of tomato yellow leaf curl virus in Florida and implications for the spread of this and other geminiviruses of tomato. Plant Dis. 83:984-988.

25. Purcifull, D. E., and Batchelor, D. L. 1977. Immunodiffusion tests with sodium dodecyl sulfate (SDS) - treated plant viruses and plant viral inclusions. Fla. Agric. Exp. Stn. Tech Bull. No. 788.

26. Reynolds, E. S. 1963. The use of lead citrate at high $\mathrm{pH}$ as an electron opaque stain in EM. J. Cell Biol. 17:208.

27. Roberts, I. M., Robinson, D. J., and Harrison, B. D. 1984. Serological relationships and genome homologies among geminiviruses. J. Gen. Virol. 65:1723-1730.

28. Sinisterra, X. H., Polston, J. E., Abouzid, A. M., and Hiebert, E. 1999. Tobacco plants transformed with a modified coat protein of tomato mottle begomovirus show resistance to virus infection. Phytopathology 89:701706.

29. Strandberg, J. O., Hiebert, E., Leibee, G. L., and Abouzid, A. M. 1991. A new geminivirus with a broad host range in the Brassicaceae. (Abstr.) Phytopathology 81:1244.

30. Studier, F. W., Rosenberg, A. H., Dunn, J. J., and Dubendorff, J. W. 1990. Use of T7 RNA polymerase to direct the expression of cloned genes. Methods Enzymol. 185:60-89.

31. Swanson, M. M., Brown, J. K., Poulos, B. T., and Harrison, B. D. 1992. Genome affinities and epitope profiles of whitefly-transmitted geminiviruses from the Americas. Ann. Appl. Biol. 121:285-296

32. Vaira, A. M., Vecchiati, M., Masenga, V., and Accotto, G. P. 1996. A polyclonal antiserum against a recombinant viral protein combines specificity with versatility. J. Virol. Methods 56:209-219.

33. van Regenmortel, M. H. V., Fauquet, C. M. Bishop, D. H. L., Carstens, E. B., Estes, M K., Lemon, S. M., Maniloff, J., Mayo, M. A. McGeoch, D. J., Pringle, C. R., and Wickner, R. B. 2000. Virus Taxonomy. Seventh Report of the International Committee on Taxonomy of Viruses. Academic Press, San Diego, CA.

34. Wege, C., and Jeske, H. 1998. Abutilon mosaic geminivirus proteins expressed and phosphorylated in Escherichia coli. J. Phytopathol. 146:613-621.

35. Wisler, G. C., Purcifull, D. E., and Hiebert, E. 1995. Characterization of the P1 protein and coding region of the zucchini yellow mosaic virus. J. Gen. Virol. 76:37-45. 